\title{
MACULAR THICKNESS CHANGES IN DIABETIC VERSUS NON DIABETIC PATIENTS AFTER UNCOMPLICATED PHACOEMULSIFICATION
}

\author{
By
Mahmoud Mohammed Madeeh Hassanin, Mohamed Khedr Mohamed and Mohamed Mohamed-Aly Ibrahim

Department of Ophthalmology, Faculty of Medicine, Al-Azhar University

Corresponding author: Mahmoud Mohammed Madeeh Hassanin,

E-mail: mahmoudmadeeh0110@gmail.com

\begin{abstract}
Background: In recent years, there has seen great progress in cataract surgery, both in the surgical technique as well as with modern phacoemulsifiers. Optical Coherence Tomography (OCT) is a noninvasive and noncontact diagnostic tool with high resolution to assess macular changes.

Purpose: To assess the impact of uncomplicated phacoemulsification on the changes of central macular thickness (CMT) values in diabetic and non-diabetic patients.

Methods: Thirty eyes of 30 subjects who underwent uneventful phacoemulsification were divided into 3 equal groups: Group I: Non diabetic patients, Group II: Diabetic patients without retinal changes and Group III: Diabetic patients with mild to moderate non-proliferative diabetic retinopathy (NPDR). Each patient was subjected to routine examination, best corrected visual acuity and CMT was assessed by OCT one day before operation, one week, one month and six months after the operation.
\end{abstract}

Results: According to CMT, significant difference was reported after one month and six months between all groups. This study showed statistically significant differences between groups one week, one month and six months postoperatively according to BCVA. Also there were statistically significant differences over the periods through BCVA in the each group, negative significant correlations between CME and BCVA after 1 month and 6 months. The mean BCVA improved progressively in the postoperative period, and it was nonsignificant correlated with duration of DM one week postoperatively. However, the correlations were significant after one month and six months. The CMT increased progressively in the postoperative periods and it significantly correlated with the duration of DM after one month and six months.

Conclusion: Diabetes influenced the central macular thickness in diabetic patients, who were more liable to changes in central macular thickness after cataract surgery even with uncomplicated cataract surgery.

Key words: Macular thickness changes, diabetic, non-diabetic, uncomplicated phacoemulsification.

\section{INTRODUCTION}

Cataract is the most common cause of blindness in the world, and it usually requires surgical removal (Song et al., 2014).

The worldwide prevalence of diabetes is on the rise, and patients with diabetes have higher risk of developing cataract compared with patients without diabetes (Srinivasan et al., 2017).

At present, the main surgical procedures are phacoemulsification and posterior chamber intraocular lens implantation (Zhu et al., 2012). 
Cystoid macular edema (CME) is one of the main causes of unfavorable visual outcomes and one of the most common complications following uncomplicated cataract surgery in patients with and without diabetes, which is measured by an alteration in CMT using optical coherence tomography (OCT) (Romero-Aroca, 2010).

OCT generates cross-sectional or three-dimensional images by measuring the echo time delay and magnitude of back-reflected light. It is a noninvasive, noncontact medical imaging modality that allows quantitative measurements of retinal thickness and volume. OCT provides images of vitreous, retinal, and choroidal structure that cannot be obtained by any other noninvasive diagnostic technique, and its scans have been compared with histologic sections seen with light microscopy (Fujimoto et al., 2020).

The present work aimed to assess the impact of uncomplicated phacoemulsification on the changes of CMT values in diabetic and non-diabetic patients.

\section{PATIENTS AND METHODS}

Thirty eyes of 30 patients with cataract who were candidates for phacoemulsification and posterior chamber intraocular lens (IOL) implantation after taking free informed written consent from all patients, divided into three equal groups:

- Group I non-diabetic patients who received the ordinary post-operative regimen prednisolone acetate ophthalmic suspension (1\%) five times/ day with gradual tapering over six weeks, gatifloxacin eye drops five times daily for six weeks, and tobramycin $(0.3 \%)$, dexamethasone $(0.1 \%)$ eye ointment at bed time for six weeks.

- Group II (DM without fundus changes) received the same regimen as group I post-operatively.

- Group III (DM with NPDR) received the same regimen as group I postoperatively.

Patients with dense media opacities such as dense cataract, corneal opacities or vitreous hemorrhage, PDR or severe NPDR, complications during cataract surgery (vitreous loss- dropped fragments- rupture capsule- postoperative corneal edema), chronic inflammatory eye conditions, patient on glaucoma therapy, any previous retinal intervention and any previous intra ocular surgery were excluded from the study.

\section{Preoperative evaluation:}

\section{History taking:}

Onset, course and duration of diminution of vision. History of ocular trauma, ocular surgery, systemic disorder and drug intake General examination: Review for systemic diseases Laboratory investigation: routine preoperative investigations.

\section{Preoperative examination: \\ ophthalmological}

Uncorrected visual acuity (UCVA), Pupil reaction, Refraction using automated refractometer, Best corrected visual acuity (BCVA), Slit lamp biomicroscopy. Intraocular pressure (IOP) measurement, Fundus examination, 
Assessment of ocular motility, Examination of ocular adnexa.

\section{Preoperative investigation:}

Calculation of IOL power and axial length. OCT scanning: Spectral-domain OCT scan of the macula was recorded using (3D OCT 2000; Topcon, Tokyo, Japan). After the patient scanning was finished, analysis protocol was used to obtain circular maps on the fovea. The macular retinal map divides the region into a central area with a radius of 500 microns, and two concentric rings inner perifoveal ring and outer parafoveal ring which were divided into four quadrants, mydriatic eye drops was instilled into patients eyes prior to OCT examination.

\section{Phacoemulsification procedure:}

Phacoemulsification and intraocular lens implantation were performed using almost the standard techniques, before surgery pupillary dilatation was achieved by $(1 \%)$ tropicamide and $(1 \%)$ cyclopentolate eye drops, ocular sterilization with a drop of povidine iodine (5\%) was used, cataract surgery was performed under local anesthesia, anterior limbal incision was made using keratome, two side ports was made by MVR, formation of the anterior chamber by viscoelastic, anterior continuous circular curvilinear capsulorhexis was performed followed by hydro dissection and hydro delineation, then phacoemulsification of the nucleus, bimanual irrigation aspiration, and implantation of IOL in the bag after widening of the wound, finally hydration of the wound and the two paracentesis. After the operation all patients received the same standard medication for 6 weeks.

\section{Postoperative examinations:}

One day after surgery: Slit lamp bio microscopy for: State of main incision, Cornea for clarity, oedema and ulcers, anterior chamber (depth and contents), Any iris abnormality, IOL regarding its position and any deposits on its surface. One week, One month and six months after surgery: Best corrected visual acuity (BCVA), Slit lamp bio microscopy, IOP, Fundus examination and OCT.

\section{Statistical analysis:}

Recorded data were analyzed using the statistical package for social sciences, version 20.0 (SPSS Inc., Chicago, Illinois, USA). Quantitative data were expressed as mean \pm standard deviation (SD). Qualitative data were expressed as frequency and percentage.

Recorded data were analyzed using the statistical package for social sciences, version 20.0 (SPSS Inc., Chicago, Illinois, USA). Quantitative data were expressed as mean \pm standard deviation (SD). Qualitative data were expressed as frequency and percentage.

\section{The following tests were done:}

- Independent-samples t-test of significance was used when comparing between two means.

- A one-way analysis of variance (ANOVA) when comparing between more than two means.

- Chi-square (X2) test of significance was used in order to compare proportions between two qualitative parameters.

- Pearson's correlation coefficient (r) test was used for correlating data. 
- The confidence interval was set to $95 \%$ and the margin of error accepted was set to $5 \%$. So, the p-value was considered significant as the following:
- P-value <0.05 was considered significant.

\section{RESULTS}

No statistically significant difference between groups according to demographic data, nor according to treatment of DM. However there was a highly statistically significant difference between group 1 and 2 according to duration of DM (Table 1).

Table (1): Comparison between the study groups as regards demographic data, age, site, treatment and duration of DM

\begin{tabular}{|c|c|c|c|c|}
\hline Parameters & $\begin{array}{l}\text { Group 1: } \\
\text { Control } \\
(\mathbf{N}=10)\end{array}$ & $\begin{array}{c}\text { Group 2: DM } \\
\text { without retinal } \\
\text { changes } \\
(\mathrm{N}=10)\end{array}$ & $\begin{array}{c}\text { Group 3: DM } \\
\text { with mild to } \\
\text { moderate } \\
\text { NPDR }(\mathrm{N}=10)\end{array}$ & $\begin{array}{c}\text { p- } \\
\text { value }\end{array}$ \\
\hline \multicolumn{5}{|l|}{ Demographic Data } \\
\hline \multicolumn{5}{|l|}{ Gender } \\
\hline Female & $5(50.0 \%)$ & $7(70.0 \%)$ & $6(60.0 \%)$ & \multirow{2}{*}{0.659} \\
\hline Male & $5(50.0 \%)$ & $3(30.0 \%)$ & $4(40.0 \%)$ & \\
\hline \multicolumn{5}{|l|}{ Age (years) } \\
\hline Mean \pm SD & $54.80 \pm 11.16$ & $62.30 \pm 7.54$ & $58.20 \pm 7.51$ & \multirow{2}{*}{0.188} \\
\hline Range & $30-66$ & $53-72$ & $44-67$ & \\
\hline \multicolumn{5}{|l|}{ Site } \\
\hline Left & $2(20.0 \%)$ & $4(40.0 \%)$ & $6(60.0 \%)$ & \multirow{2}{*}{0.189} \\
\hline Right & $8(80.0 \%)$ & $6(60.0 \%)$ & $4(40.0 \%)$ & \\
\hline $\begin{array}{l}\text { Treatment of DM } \\
\text { Insulin }\end{array}$ & & $3(30.0 \%)$ & $5(50.0 \%)$ & \multirow{2}{*}{0.648} \\
\hline Oral & & $7(70.0 \%)$ & $5(50.0 \%)$ & \\
\hline $\begin{array}{l}\text { Duration of DM (months) } \\
\text { Mean } \pm \text { SD }\end{array}$ & & $106.80 \pm 19.14$ & $183.60 \pm 36.24$ & \multirow[t]{2}{*}{$<0.001$} \\
\hline Range & & $84-144$ & $144-240$ & \\
\hline
\end{tabular}

Central macular thickness showed statistically significant difference over the periods in the each group. There were no significant differences between all groups preoperative and after one week postoperatively. But, there was a statistically significant difference after one month and six months postoperatively (Table 2). 
Table (2): Comparison between groups according to central macular thickness and the extent of the difference over the periods through CMT in the each group

\begin{tabular}{|c|c|c|c|c|}
\hline $\begin{array}{l}\text { Groups } \\
\text { Central Macular } \\
\text { thickness }\end{array}$ & $\begin{array}{l}\text { Group 1: } \\
\text { Control } \\
(\mathrm{N}=10)\end{array}$ & $\begin{array}{c}\text { Group 2: DM } \\
\text { without retinal } \\
\text { changes }(N=10)\end{array}$ & $\begin{array}{c}\text { Group 3: } \\
\text { DM with mild to } \\
\text { moderate NPDR } \\
(\mathrm{N}=10)\end{array}$ & P-value \\
\hline \multicolumn{4}{|l|}{ Pre-operative } & \multirow{3}{*}{0.091} \\
\hline Mean \pm SD & $189.60 \pm 23.84$ & $182.40 \pm 15.94$ & $211.90 \pm 43.47$ & \\
\hline Range & $160-225$ & $165-209$ & $154-273$ & \\
\hline \multicolumn{4}{|l|}{1 week } & \multirow{3}{*}{0.121} \\
\hline Mean \pm SD & $198.30 \pm 27.92$ & $200.10 \pm 14.51$ & $228.20 \pm 51.93$ & \\
\hline Range & $166-243$ & $183-223$ & $165-303$ & \\
\hline \multicolumn{4}{|l|}{1 month } & \multirow{3}{*}{0.017} \\
\hline Mean \pm SD & $211.80 \pm 39.59$ & $227.80 \pm 38.84$ & $280.60 \pm 71.57$ & \\
\hline Range & $171-290$ & $190-300$ & $200-413$ & \\
\hline \multicolumn{4}{|l|}{6 month } & \multirow{3}{*}{0.003} \\
\hline Mean \pm SD & $201.20 \pm 28.52$ & $204.90 \pm 18.06$ & $274.70 \pm 77.47$ & \\
\hline Range & $172-261$ & $186-247$ & $190-402$ & \\
\hline p-value & 0.025 & $<0.001$ & 0.002 & \\
\hline \multicolumn{5}{|l|}{ Mean diff. } \\
\hline Pre \& after 1week & $8.70 \pm 3.39$ & $10.50 \pm 4.10$ & $38.60 \pm 15.05 a b$ & 0.005 \\
\hline Pre \& after 1month & $22.20 \pm 8.66$ & $38.20 \pm 14.90 \mathrm{a}$ & $91.00 \pm 35.49 \mathrm{ab}$ & $<0.001$ \\
\hline Pre \& after 6months & $11.60 \pm 4.52$ & $15.30 \pm 5.97$ & 85.10 $\pm 33.19 a b$ & $<0.001$ \\
\hline
\end{tabular}

Best corrected visual acuity (BCVA) increased significantly over the periods in the each group. The mean difference in BCVA shows no statistical significant difference between groups after one week. But, there was a statistically significant difference after one month and six months postoperatively (Table 3).

Table (3): Comparison between groups according to BCVA and the extent of the difference over the periods through BCVA in the each group

\begin{tabular}{|c|c|c|c|c|}
\hline BCVA & $\begin{array}{c}\text { Group 1: } \\
\text { Control } \\
\mathrm{N}=10)\end{array}$ & $\begin{array}{l}\text { Group 2: DM } \\
\text { without retinal } \\
\text { changes }(\mathrm{N}=10)\end{array}$ & $\begin{array}{l}\text { Group 3: DM with } \\
\text { mild to moderate } \\
\text { NPDR }(\mathrm{N}=10)\end{array}$ & p-value \\
\hline \multicolumn{5}{|l|}{ Pre } \\
\hline Mean \pm SD & $0.16 \pm 0.03$ & $0.14 \pm 0.02$ & $0.13 \pm 0.02 \mathrm{a}$ & \multirow{2}{*}{0.021} \\
\hline Range & $0.125-0.2$ & $0.125-0.16$ & $0.1-0.16$ & \\
\hline \multicolumn{5}{|l|}{1 week } \\
\hline Mean \pm SD & $0.30 \pm 0.10$ & $0.25 \pm 0.03 \mathrm{a}$ & $0.21 \pm 0.04 \mathrm{ab}$ & \multirow{2}{*}{0.017} \\
\hline Range & $0.2-0.5$ & $0.2-0.32$ & $0.16-0.25$ & \\
\hline \multicolumn{5}{|l|}{1 month } \\
\hline Mean \pm SD & $0.49 \pm 0.15$ & $0.42 \pm 0.14$ & $0.29 \pm 0.08 \mathrm{ab}$ & \multirow{2}{*}{0.006} \\
\hline Range & $0.25-0.8$ & $0.2-0.63$ & $0.2-0.4$ & \\
\hline \multicolumn{5}{|l|}{6 month } \\
\hline Mean \pm SD & $0.59 \pm 0.13$ & $0.50 \pm 0.11$ & $0.38 \pm 0.09 \mathrm{ab}$ & \multirow{2}{*}{$<0.001$} \\
\hline Range & $0.4-0.8$ & $0.32-0.63$ & $0.2-0.5$ & \\
\hline p-value & $<0.001$ & $<0.001$ & $<0.001$ & \\
\hline \multicolumn{5}{|l|}{ Mean diff. } \\
\hline Pre \& after 1 week & $0.13 \pm 0.11$ & $0.10 \pm 0.04$ & $0.08 \pm 0.02$ & 0.198 \\
\hline Pre \& after 1 month & $0.33 \pm 0.13$ & $0.28 \pm 0.14$ & $0.17 \pm 0.06 \mathrm{ab}$ & 0.013 \\
\hline Pre \& after 6months & $0.43 \pm 0.12$ & $0.36 \pm 0.11$ & $0.25 \pm 0.07 \mathrm{ab}$ & 0.002 \\
\hline
\end{tabular}


Negative significant correlation between central macular thickness and BCVA after 1 month and after 6 months

in groups 2, 3 but also in group 3 there were negative significant correlation preoperatively (Table 4).

Table (4): Correlation between central macular thickness and BCVA, using Pearson correlation Coefficient in group 2, 3

\begin{tabular}{|c|c|c|c|c|c|c|c|c|c|}
\hline \multirow{2}{*}{\multicolumn{2}{|c|}{ BCVA }} & \multicolumn{2}{|c|}{ Pre-operative } & \multicolumn{2}{|c|}{1 week } & \multicolumn{2}{|c|}{1 month } & \multicolumn{2}{|c|}{6 month } \\
\hline & & 2 & 3 & 2 & 3 & 2 & 3 & 2 & 3 \\
\hline \multirow{2}{*}{ Pre } & $\mathrm{r}$ & -0.026 & -0.665 & & & & & & \\
\hline & p-value & 0.942 & 0.036 & & & & & & \\
\hline \multirow{2}{*}{1 week } & $\mathrm{r}$ & & & 0.131 & -0.287 & & & & \\
\hline & p-value & & & 0.719 & 0.422 & & & & \\
\hline \multirow{2}{*}{1 month } & $\mathrm{r}$ & & & & & -0.903 & -0.667 & & \\
\hline & p-value & & & & & $<0.001$ & 0.035 & & \\
\hline \multirow{2}{*}{6 months } & $\mathrm{r}$ & & & & & & & -0.625 & -0.611 \\
\hline & p-value & & & & & & & 0.035 & 0.039 \\
\hline
\end{tabular}

Statistically significant correlation between duration of DM with central macular thickness also BCVA after 1

month and 6 months in group 2, but not statistically significant correlation in group 3 (Table 5).

Table (5): Correlation between age, duration of DM with central macular thickness and BCVA, using Pearson correlation Coefficient in group 2, 3

\begin{tabular}{|c|c|c|c|c|c|c|c|c|}
\hline \multirow{3}{*}{ Groups } & \multicolumn{4}{|c|}{ Age (years) } & \multicolumn{4}{|c|}{ Duration of DM (months) } \\
\hline & \multicolumn{2}{|c|}{$\mathbf{r}$} & \multicolumn{2}{|c|}{ p-value } & \multicolumn{2}{|c|}{$\mathbf{r}$} & \multicolumn{2}{|c|}{ p-value } \\
\hline & 2 & 3 & 2 & 3 & 2 & 3 & 2 & 3 \\
\hline \multicolumn{9}{|l|}{ Central Macular thickness } \\
\hline Pre oper & -0.076 & 0.282 & 0.835 & 0.430 & 0.622 & 0.368 & 0.055 & 0.295 \\
\hline 1 week & 0.414 & 0.362 & 0.234 & 0.304 & 0.428 & 0.289 & 0.218 & 0.417 \\
\hline 1 month & 0.042 & 0.406 & 0.908 & 0.244 & 0.679 & 0.136 & 0.031 & 0.707 \\
\hline 6 months & 0.033 & 0.455 & 0.928 & 0.186 & 0.725 & 0.352 & 0.018 & 0.318 \\
\hline \multicolumn{9}{|l|}{ BCVA } \\
\hline Pre oper & -0.014 & 0.195 & 0.969 & 0.590 & 0.198 & 0.046 & 0.583 & 0.899 \\
\hline 1 week & 0.272 & 0.069 & 0.448 & 0.851 & 0.458 & -0.004 & 0.183 & 0.992 \\
\hline 1 month & -0.166 & -0.206 & 0.646 & 0.568 & -0.616 & 0.310 & 0.028 & 0.383 \\
\hline 6 months & -0.565 & -0.045 & 0.089 & 0.903 & -0.819 & 0.184 & 0.004 & 0.611 \\
\hline
\end{tabular}

The following photos (Figure $\mathbf{1} \mathbf{a}, \mathbf{b}, \mathbf{c}$ and d) showed OCT of a patient of this study from group 1. It was undertaken preoperatively, one week, one month and six months postoperatively. 

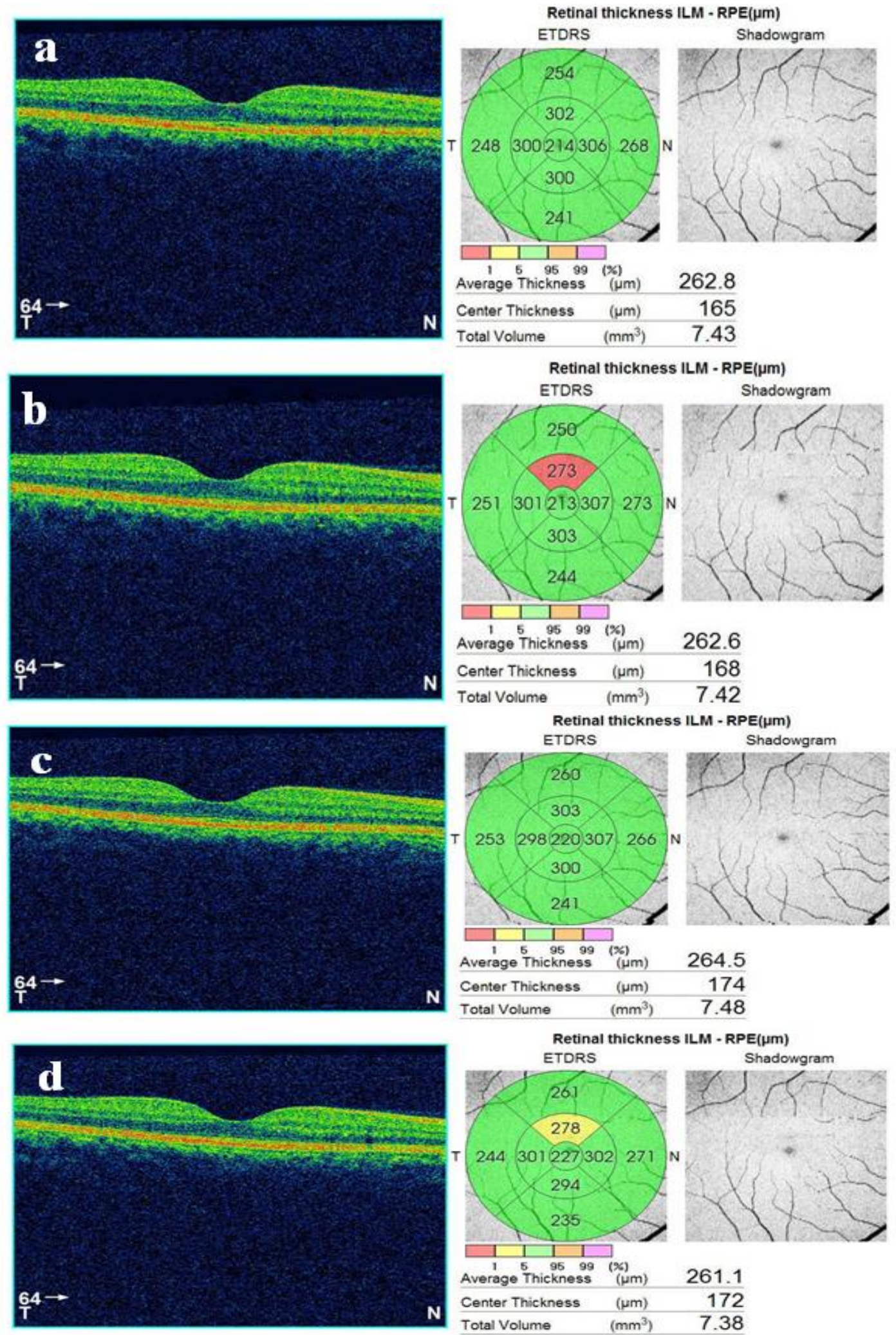

Figure (1): A case from group 1.

(a): Preoperative OCT, (b): Postoperative OCT (after one week), (c): Postoperative OCT(after one month). (d): Postoperative OCT (after six months) 
The following photos (Figure $2 \mathbf{a}, \mathbf{b}, \mathbf{c}$ and d) showed OCT of a patient of this study from Group 2. It was undertaken
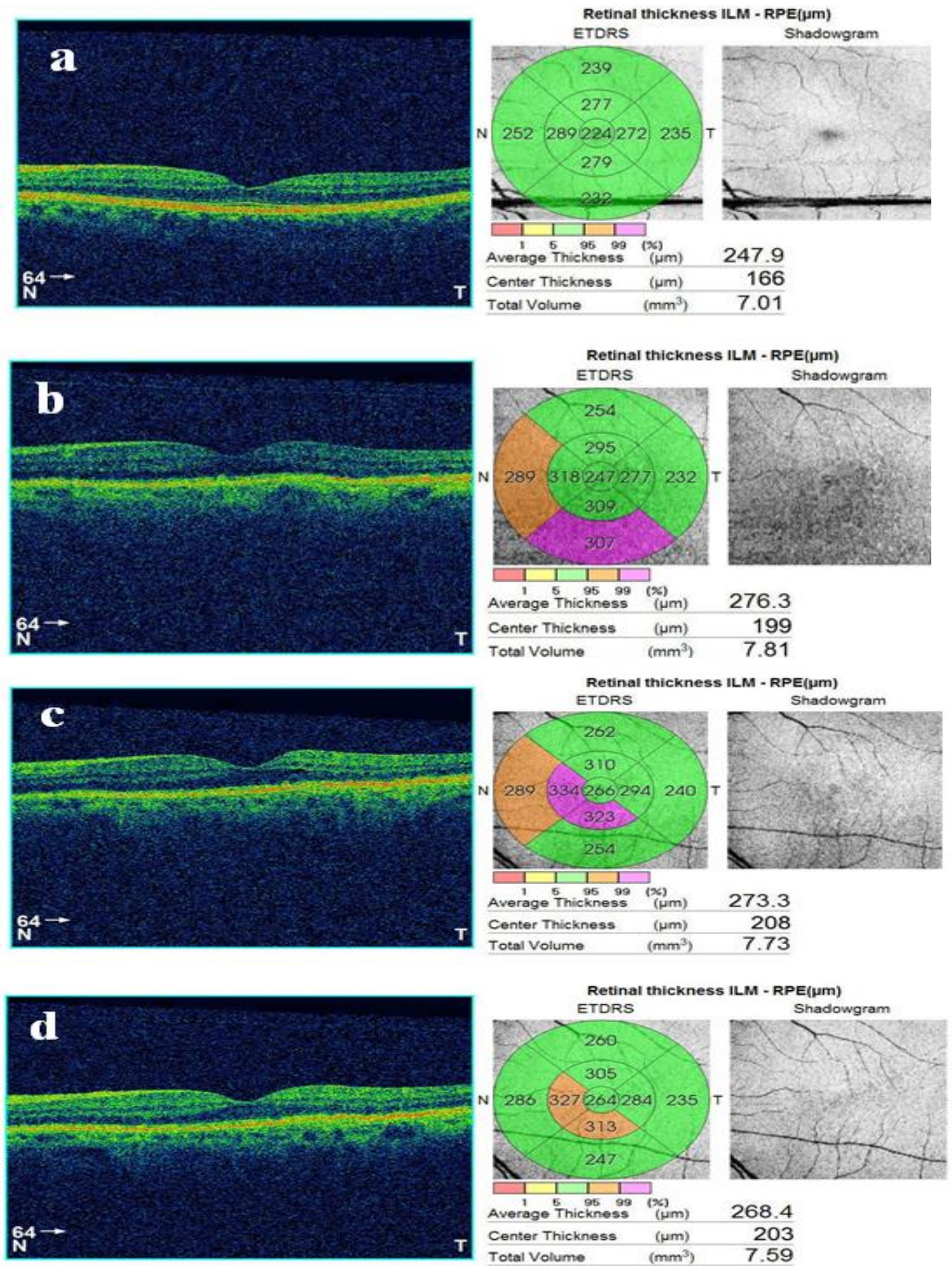

Figure (2): A case from group 2

(a): Preoperative OCT, (b): Postoperative OCT (after one week), (c): Postoperative OCT (after one month). (d): Postoperative OCT (after six months) 
The following photos (Figure $\mathbf{3} \mathbf{a}, \mathbf{b}, \mathbf{c}$ and d) showed OCT of a patient of this study from Group 3. It was undertaken
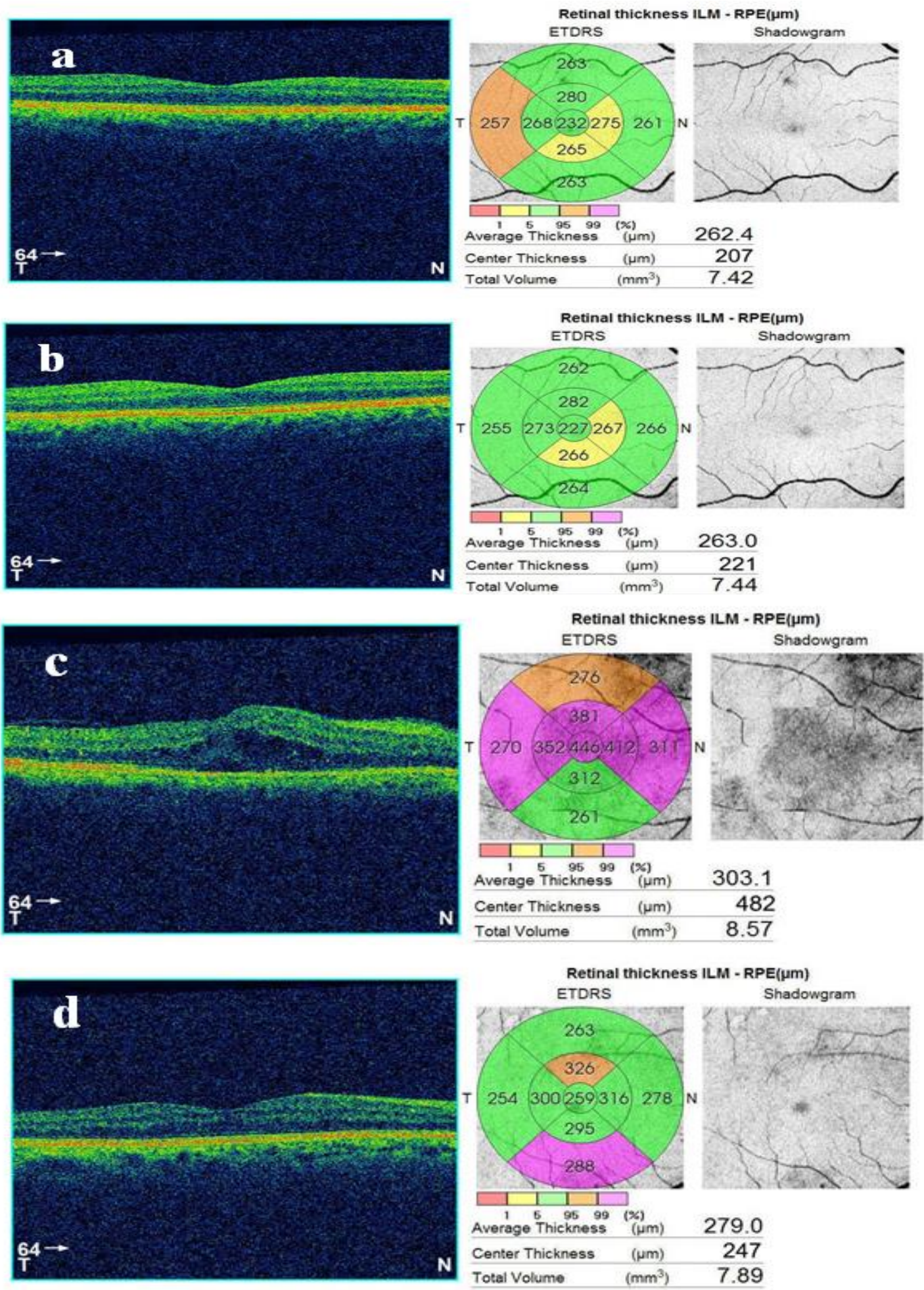

Figure (3): A case from group 3

(a): Preoperative OCT, (b): Postoperative OCT (after one week), (c): Postoperative OCT (after one month). (d): Postoperative OCT (after six months) 


\section{DISCUSSION}

Phacoemulsification (phaco) is one of the most widely used cataract surgery techniques nowadays. Various factors involved in phaco can influence the tissue structures of the eyeball. Unlike other maneuvers, ultrasonic energy and fluidics produce mechanical effects that cause an inflammatory reaction, compression, and hypoxia on the tissue. Every step of this maneuver can cause direct effects on tissue and instantaneous pressure fluctuation (Day et al., 2016).

In current study, there was no statistical difference found concerning age or gender distribution between diabetics and control group. These results were in agreement with Wang and Cheng (2014) who found that there were no differences in age and sex. Eriksson et al. (2011) showed that the majority were men without significant difference between both groups.

Insulin is one of the most important therapeutic measures in the treatment of DM. In current study, according to treatment of each group; in group III there was $50.0 \%$ patient on insulin injection or on oral hypoglycemic, in group II, the majority were $70.0 \%$ patients on oral hypoglycemic versus $30.0 \%$ patients on insulin, with significant difference between the groups. Similarly, Zhao et al. (2014) reported that the significant association between insulin use and risk of DR was detected.

In certain cross-sectional study by Silpa-Archa and Sukhawarn (2012) the result demonstrated that the patients who had received insulin treatment were more likely to suffer from DR than those who had not.
According to CMT, all groups showed a significant increasing after one week and 4 weeks, then gradual resolving after 6 months postoperatively. However, the increasing in CMT were more in diabetic groups after one month ,also the resolving were more in the non-diabetic group after 6 months postoperatively. In current study, the mean CMT shows insignificant difference between the three groups preoperative, one week postoperative, but significant difference was reported after one month and six months. This indicates that compared with the control group and with diabetic patients with no DR, the phacoemulsification surgery had a stronger effect on the blood-aqueous barrier of diabetic patients with mild NPDR. Surgery itself can cause inflammatory response by releasing prostaglandins, which plays an important role in the occurrence of macular thickening as reported by Bannale et al. (2012).

Also, our finding was supported by Liu et al. (2015) study which assesses the impact of uncomplicated phacoemulsification on the changes of CMT values and BCVA in both diabetic patients without DR and diabetic patients with mild to moderate NPDR. They found in both groups, a significant increase in CMT values were found after 1 month, 3 months and 6 months postoperatively. CMT values in diabetic patients with NPDR showed a statistically significant increase after postoperative 1 month compared with diabetic patients without DR. No statistically significant increase in CMT values was observed after postoperative 3 and 6 months in diabetic patients without DR but diabetic patients with mild to moderate NPDR had a higher 
incidence of subclinical macular thickening after uncomplicated phacoemulsification than diabetic patients without DR. The results indicate that uncomplicated phacoemulsification has some effect upon the underlying pathophysiology of retinopathy.

Oh et al. (2014) showed that diabetic patients may be susceptible to developing postoperative subclinical retinal swelling or clinical ME after cataract surgery.

In contrast, Wang and Cheng (2014) reported that there was no difference in preoperative CMT between the two groups. A significant increase in thickness in each group was observed after 4 weeks postoperative in both groups. But there were no significant differences in mean CMT between the groups preoperatively and after 1 week, 2 weeks, and 4 weeks postoperatively.

Eriksson et al. (2011) found that thickness of the CMT increased significantly between the preoperative measurements and the 6-week follow up in both diabetics and controls. There was, however, no significant difference between the two groups.

In current study, regarding best corrected visual acuity (BCVA), statistical significant difference between diabetic groups II, III and control group in preoperative period was reported. Also, this study shows statistically significant difference between groups after one week, one month and after six months postoperatively.

Our finding was supported by Liu et al. (2015) who assessed the impact of uncomplicated phacoemulsification on the changes of CMT values and BCVA in both diabetic patients without DR and diabetic patients with mild to moderate NPDR. They found that uncomplicated phacoemulsification significantly improved BCVA after postoperative 1 month and 6 months in both diabetic patients without DR and diabetic patients with mild to moderate NPDR. However, visual outcomes were not compromised in diabetic patients with mild to moderate NPDR after postoperative 1 month and 6 months, indicating that the changes in CMT values remained subclinical in diabetic patients with NPDR.

Despite these macular alterations, visual acuity improved significantly after cataract surgery in all patients in this study, while none of the patients showed clinical CME (Tsilimbaris et al., 2012).

The present study showed statistically significant difference over the periods through BCVA in the each group. Similar finding by El-Saadani et al. (2018) found that, regarding best corrected visual acuity (BCVA) in both the diabetic and control groups has significant improvement after 1 month postoperatively.

In current study, there was a negative significant correlation between central macular thickness and BCVA after 1 month and 6 months. In harmony with current results, Islam et al. (2016) found that there was moderate correlation between foveal thickness and visual acuity.

There was a negative correlation between CMT and visual acuity measurement and a negative linear regression as reported by Yassin et al. (2019). 
In this study, the mean BCVA was non-significant correlated with duration of DM one week postoperative. However, a negative significant correlation was reported after one month and six months.

A significant positive correlation between the duration of diabetes with visual acuity (in LogMAR) was reported by Yassin et al. (2019). Also, Bressler et al. (2012) found shorter diabetes duration was also associated with better VA outcomes.

In current study, CMT increased progressively in the postoperative period and it was significantly correlated with the duration of DM after one month and six months postoperatively. This finding was not surprising because the duration of DM is recognized as a significant factor in the progression of DR in all diabetic patients. Similarly, Ghosh et al. (2015) found the duration of diabetes has a significant correlation with CMT. Also, Musat et al. (2015) found glycemic control is a conclusively identifies risk factor for retinopathy progression as well as for DME. Duration of diabetes is strongly correlated with prevalence and incidence of macular edema, retinopathy progression, and other diabetic complications.

\section{CONCLUSION}

OCT is valuable, noninvasive, reproducible device to detect pre and postoperative changes in macular thickness and it represents the single most important diagnostic and prognostic tool in management of macular edema.

Diabetes influences the central macular thickness in diabetic patients, who are more liable to changes in central macular thickness after cataract surgery even if uncomplicated cataract surgery.

Additionally, duration of diabetes was considered a significant risk factor for visual acuity impairment in patients with DME.

\section{REFERENCES}

1. Bannale SG, Pundarikaksha $H$ and Sowbhagya H. (2012): A prospective, openlabel study to compare the efficacy and the safety of topical loteprednol etabonate and topical flurbiprofen sodium in patients with post-operative inflammation after cataract extraction. Journal of clinical and diagnostic research: JCDR, 6: 1499-.1514

2. Bressler SB, Qin H, Beck RW, Chalam KV, Kim JE, Melia M and Wells JA $3^{\text {rd }}$ (2012): Factors associated with changes in visual acuity and central subfield thickness at 1 year after treatment for diabetic macular edema with ranibizumab. Archives of Ophthalmology, 130: 1153-1161.

3. Day AC, Gore DM, Bunce C and Evans JR. (2016): Laser-assisted cataract surgery versus standard ultrasound phacoemulsification cataract surgery. Cochrane Database of Systematic Reviews, 21: 379-392.

4. El-Saadani AE-K, Mandour $S$ and Laymouna M. (2018): Evaluation of macular changes after uncomplicated phacoemulsification surgery in diabetic patients using optical coherence tomography. Menoufia Medical Journal, 31: 289-292.

5. Eriksson U, Alm A, Bjärnhall G, Granstam E and Matsson AW. (2011): Macular edema and visual outcome following cataract surgery in patients with diabetic retinopathy and controls. Graefe's Archive for Clinical and Experimental Ophthalmology 249: 349-359.

6. Fujimoto JG, Schmitt J, Swanson E,Aguirre AD and Jang Ik. (2020): The Development of Optical Coherence Tomography. Cardiovascular OCT Imaging. pbl. Springer, 1-23.

7. Ghosh S, Bansal P, Shejao H, Hegde R, Roy D and Biswas S. (2015): Correlation of morphological pattern of optical coherence 
tomography in diabetic macular edema with systemic risk factors in middle aged males. International Ophthalmology, 35: 3-10.

8. Islam F, Ashraf M, Zafar S and Masood H. (2016): Retinal thickness and visual acuity in diabetic macular edema: An optical coherence tomography-based study. Journal of the College of Physicians and Surgeons Pakistan, 26: 598-601.

9. Liu J, Jones RE, Zhao J, ZHANG J and ZHANG F. (2015): Influence of uncomplicated phacoemulsification on central macular thickness in diabetic patients: a metaanalysis. PloS one, 10: 121-143.

10. Musat O, Cernat C, Labib M, Gheorghe A, Toma O, Zamfir $M$ and Boureanu AM. (2015): diabetic Macular Edema. Rom J Ophthalmol., 59: 133-136.

11. Oh J-H, Chuck RS, Do JR and Park CY. (2014): Vitreous hyper-reflective dots in optical coherence tomography and cystoid macular edema after uneventful phacoemulsification surgery. PloS one, 9: 950966.

12. Romero-Aroca P. (2010): Targeting the pathophysiology of diabetic macular edema. Am Diabetes Assoc., 33(11): 2484-2485.

13. Silpa-Archa $S$ and Sukhawarn R. (2012): Prevalence and associated factors of diabetic retinopathy in Chandrubeksa Hospital, Directorate of Medical services, Royal Thai Air Force. J Med Assoc Thai., 95: S43-S49.

14. Song E, Sun H, Xu Y, Ma Y, Zhu H and Pan CW. (2014): Age-related cataract, cataract surgery and subsequent mortality: a systematic review and meta-analysis. PloS one, 9: 112 154.
15. Srinivasan S, Raman R, Swaminathan G,Ganesan S Kulothungan $V$ and Sharma $T$. (2017): Incidence, progression, and risk factors for cataract in type 2 diabetes. Investigative Ophthalmology \& Visual Science, 58: 59215929.

16. Tsilimbaris M, Diakonis VF, Kymionis GD, Eleftheriadou MI, Fragkiskou S, Moschandreas J, Frueh BE, Epstein D and Pallikaris AI. (2012): Prospective study of foveal thickness alterations after cataract surgery assessed by optical coherence tomography. Ophthalmologica, 228: 53-58.

17. Wang K-Y and Cheng C-K. (2014): Central retinal thickness changes and visual outcomes following uncomplicated small-incision phacoemulsification cataract surgery in diabetic without retinopathy patients and nondiabetic patients. Taiwan Journal of Ophthalmology, 4: 33-39.

18. Yassin SA, SM AL, Alromaih AZ and Alrushood AA. (2019): Optical coherence tomography patterns of diabetic macular edema in a Saudi population. Clin Ophthalmol., 13: 707-714.

19.Zhao C, Wang W, Xu D, Li H, Li M and Wang F. (2014): Insulin and risk of diabetic retinopathy in patients with type 2 diabetes mellitus: data from a meta-analysis of seven cohort studies. Diagn Pathol., 9: 130-147.

20.Zhu X-f, Zou H-d, Yu Y-f, Sun $Q$ and Zhao N-Q. (2012): Comparison of blue lightfiltering IOLs and UV light-filtering IOLs for cataract surgery: a meta-analysis. PloS one, 7: 33-53. 
التغير ات في سمك ماقو لة العين فى المرضي المصسابين بالسكرى و غير المصابين بعد عملية إزالة المباه البيضاء بالموجات فوق الصوتية بدون مضاعفات

محمود محمد مديح حسانين, محمد خضـر محمد، محمـ محمد علي ابراهيم

قسم طب وجراحة العين، كلية الطب، جامعة الأزهر

E-mail: mahmoudmadeeh0110@gmail.com

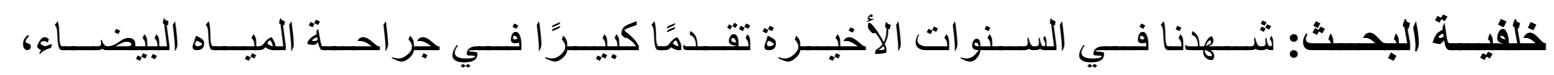

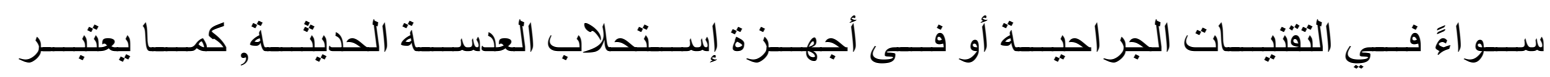

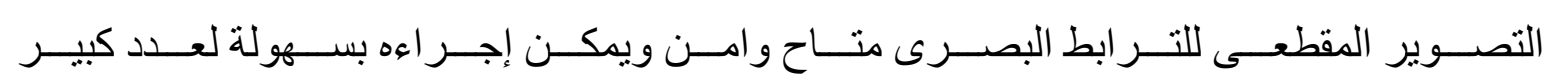

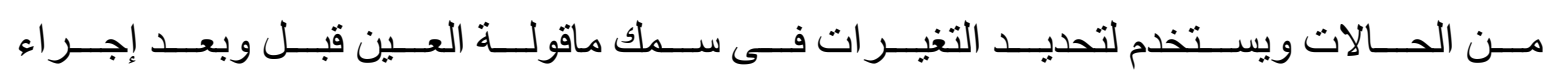
العملية و هو يمثل الطريقة الأكثر أهمية ودقة فى متابعة علاج إرتثاحات الثبكية.

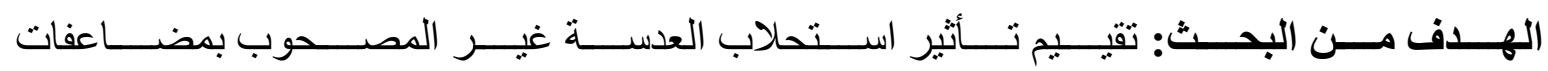

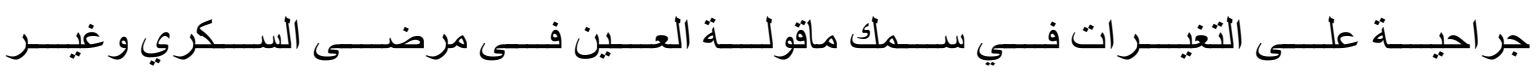
المصابين بالسكري.

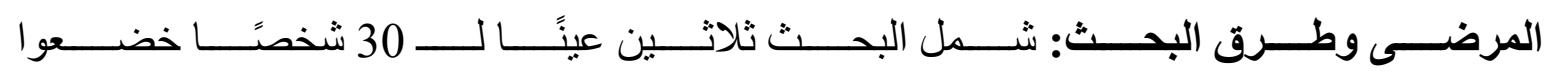

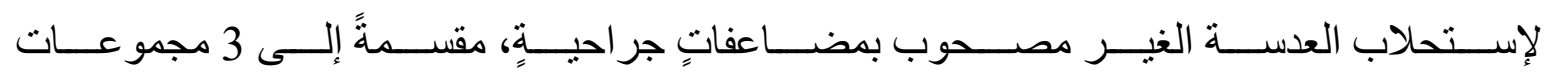

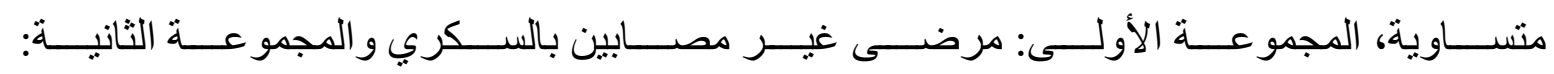

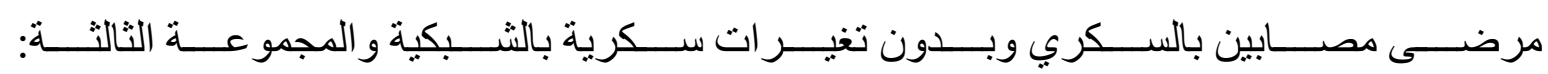

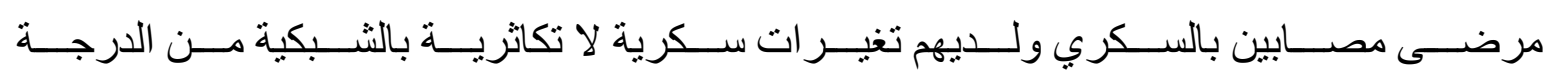

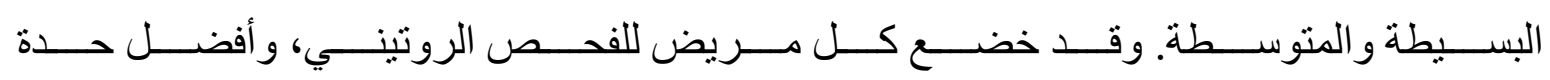

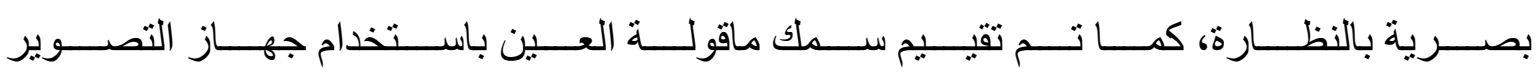

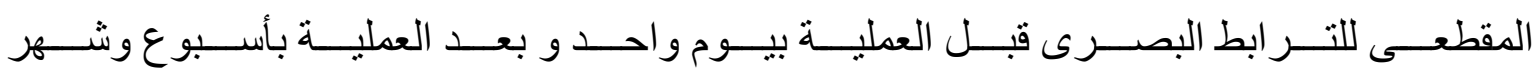
وبعد ستة أشثر.

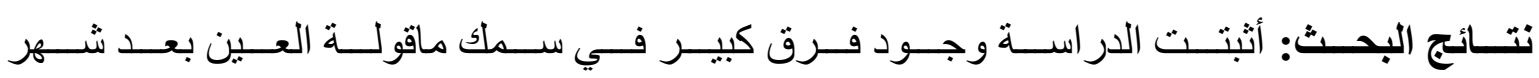

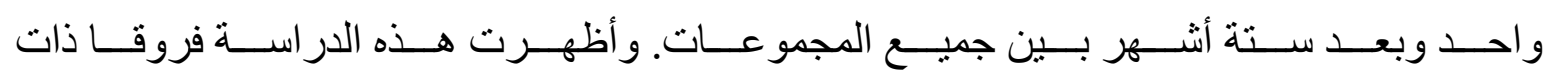

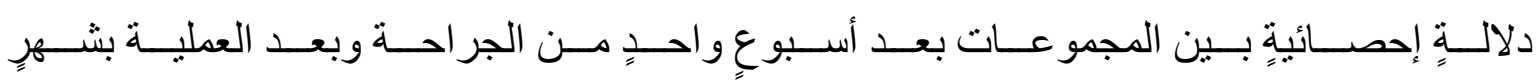




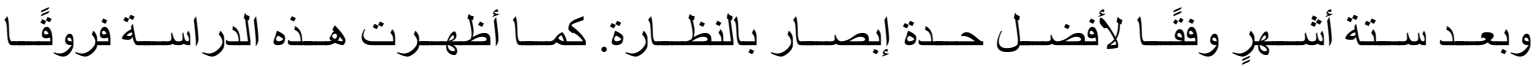

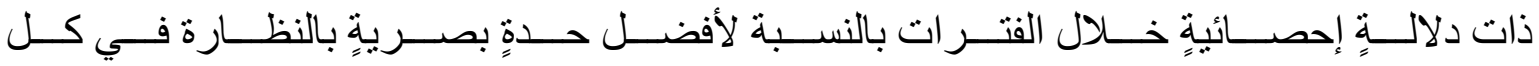

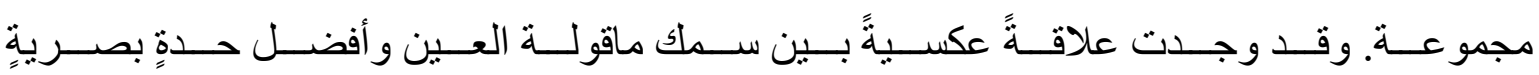

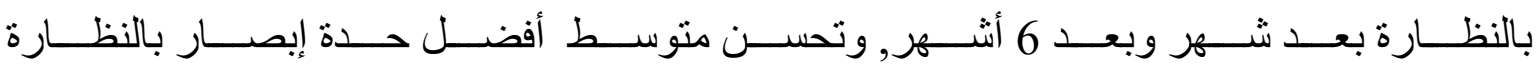

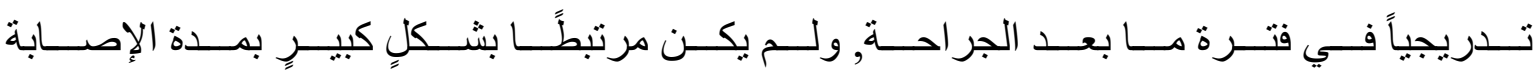

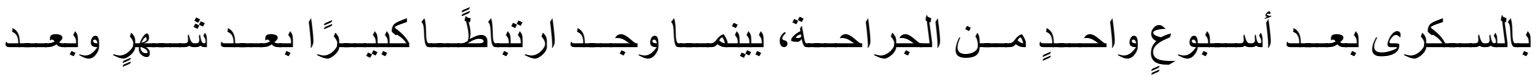

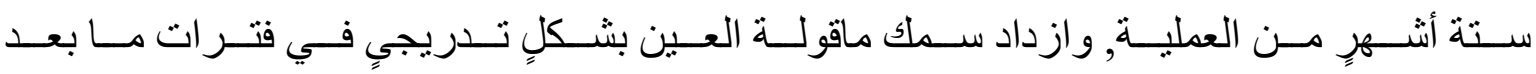
الجر احة مرتبط بشكلٍ كبيرٍٍ بمدة الإصابة بالسكرى بعد شهرٍ وبعد ستة أنشهرِ.

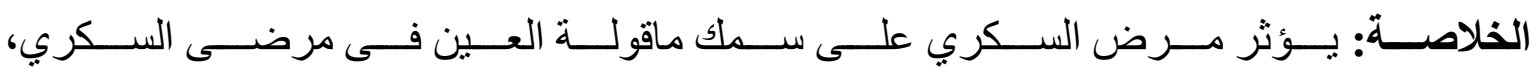

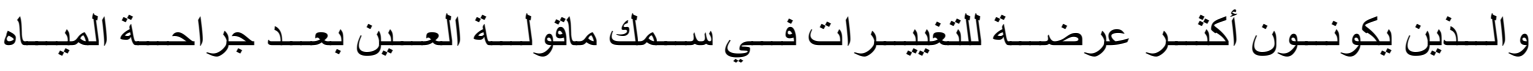
البيضاء حتى وان حدثت بدون مضاعفات جر احية.

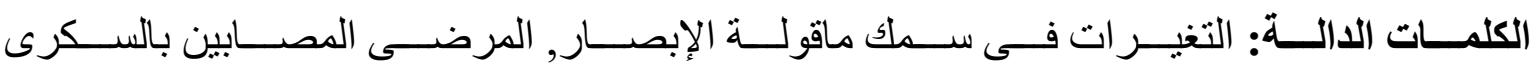
و غير المصابين, إزالة المياه البيضاء بالموجات فوق الصوتية بدون مضاعفاتٍ. 